\title{
TRANSLATION OF PAREMIOLOGICAL UNITS \\ FROM ENGLISH INTO UKRAINIAN TAKING \\ INTO ACCOUNT THEIR TYPOLOGICAL DIFFERENCES
}

\section{ПЕРЕКЛАД ПАРЕМІОЛОГІЧНИХ ОДИНИЦЬ \\ З АНГЛІЙСЬКОЇ НА УКРАЇНСЬКУ МОВУ \\ З УРАХУВАННЯМ ТИПОЛОГІЧНИХ ВІДМІННОСТЕЙ}

\section{Olena Dmytrenko ${ }^{1}$ \\ Oleksandr Kalnik ${ }^{2}$}

DOI: https://doi.org/10.30525/978-9934-588-15-0-109

Abstract. Comparison of praseological units, idioms, proverbs and sayings of different peoples clearly demonstrates the degree of their substantive closeness as well as the differences between them. This article contributes to their further study, proper understanding, comparative analysis and adequate use in oral and written speech. The relevance of this study is the need to deepen the knowledge of foreign proverbs and sayings, including English ones. This requires careful consideration, as differences between the original language and the language of translation (lexical, grammatical, semantic, as well as historical and cultural differences) can lead to misinterpretation of paroemias. That is why in this article we consider the peculiarities of the translation of English proverbs and sayings into the Ukrainian language, taking into account different linguistic features. The object of our study is the translation of widely used English paroemialogical units as well as variants of their equivalents into Ukrainian. The purpose of the article is to identify lexical, semantic and structural features of English proverbs and sayings and to clarify the specifics of their translation into Ukrainian. To achieve this goal, we have used the comparative method, the deduction method, the logical-semantic analysis, the descriptive method, and the method of analyzing dictionary definitions. The scientific novelty is that for

\footnotetext{
${ }^{1}$ Candidate of Philological Sciences, Associate Professor,

Poltava National Technical Yuri Kondratyuk University, Ukraine

${ }^{2}$ Candidate of Pedagogic Sciences, Associate Professor,

Poltava National Technical Yuri Kondratyuk University, Ukraine

(C) Olena Dmytrenko, Oleksandr Kalnik
} 
the first time there is a detailed study of the problem of the functioning of English paroemias in the context of the translation process. Comparative analysis of English and Ukrainian paroemialogical units is carried out using different sayings and proverbs as examples, taking into account the expediency of this or that variant of translation and correct interpretation.

\section{1. Ветуп}

Порівняння фразеологізмів, ідіом, прислів'їв та приказок різних народів чітко демонструє ступінь їхньої змістової близькості й, навпаки, вказує на відмінності між ними. Дане дослідження сприяє їх подальшому вивченню, правильному розумінню, порівняльному аналізу та адекватному вживанню в усному й писемному мовленні. Актуальність даного дослідження полягає у необхідності поглиблення знань про іншомовні, зокрема англійські, прислів'я і приказки. Це потребує детального розгляду, адже відмінності між мовою оригіналу й мовою перекладу - лексичні, граматичні, семантичні, а також історико-культурні розходження - можуть стати причиною неправильної інтерпретації паремій. Саме тому в даній роботі ми розглядаємо особливості перекладу англійських прислів'їв і приказок українською мовою, враховуючи різні мовні особливості. Об'єктом нашої студії $є$ переклад широковживаних англійських пареміологічних одиниць та варіанти їхніх еквівалентів в українській мові.

Метою статті є виявлення лексичних, семантичних та структурних особливостей англійських прислів'їв і приказок, а також з'ясування специфіки їх перекладу українською мовою. Задля досягнення мети нами використано компаративний метод, метод дедукції, логіко- семантичний аналіз, описовий метод та метод аналізу словникових дефініцій.

Наукова новизна полягає у тому, що вперше відбувається детальне дослідження проблеми функціонування англійських паремій у розрізі процесу перекладу. Здійснюється порівняльний аналіз англійських та українських пареміологічних одиниць на матеріалі різнотипних прислів”ів і приказок з урахуванням доцільності того чи того варіанту перекладу та коректної інтерпретації. Проводиться співставлення граматичних, синтаксичних, лексичних та семантичних специфічних рис обох варіантів на матеріалі лаконічних, однак наповнених глибоким смислом паремій. 


\section{2. Перекладацький аспект у порівнянні паремій}

Згадуючи про відмінності між фразеологічними одиницями у мовах різних народів, доцільно зазначити, що кожний із них бачить реальний світ по-своєму. Це означає, що шлях від реального світу до поняття і далі до словесного вираження є різним для кожної нації. Зважаючи на те, що наша свідомість побудована як колективно, так і індивідуально, мова відображає дійсність від реального світу до мислення та від мислення до мови. Отже, мислення і культура пов'язані так сильно, що складають єдине ціле та є майже невіддільними один від одного.

Ми розділяємо думку Тер-Мінасової С.Г., яка стверджує, що навколишній світ людини можна уявити в трьох формах: реальна картина світу, культурна (понятійна) картина світу, мовна картина світу. Реальною картиною світу вважається об'єктивне надлюдське буття, тобто світ, що оточує людину. Культурна, або понятійна картина світу відображує реальну картину крізь призму понять, сформованих на основі певних уявлень людини, отриманих за допомогою органів чуття, і тих, які пройшли крізь їі свідомість, як колективну, так i індивідуальну [7, с. 41].

Порівнюючи й аналізуючи систему англійських i українських прислів'їв і приказок, стає зрозумілим, що вони є досить різними за своїми семантичними та лексичними особливостями. Це пояснюється різними історичними, соціальними та економічними умовами розвитку, а також різним менталітетом двох етносів. Отже, вони відрізняються так само, як i обставини розвитку двох країн: географічним положенням та кліматом, відмінностями у їх національній свідомості й самоідентифікації, духовних цінностях, ментальності та самих мовах, у яких простежуються ці розбіжності.

Слід зазначити, що багато прислів'їв і приказок англійської та української мов $є$ полісемантичними, що робить їх досить подібними i спрощує процес перекладу, пояснення та порівняння. Обираючи найточніший український еквівалент для англійських паремій, слід керуватися таким критерієм, як аналогія, принаймні по відношенню до основного значення фразеологічної одиниці. Існує ціла низка прислів ’ї і приказок, які легко перекладені українською мовою та $є$ повними еквівалентами тексту оригіналу. Наприклад, Seize the bull 
by horns - взяти бика за роги. Інші паремії потребують пояснення, адже в них немає нічого спільного з українськими варіантами. До таких слід віднести англійську приказку Between the devil and deep blue sea, що дослівно перекладається як «між дияволом і глибоким синім морем» i, відповідно, не несе у собі смислового навантаження. Ця пареміологічна одиниця перекладається українською мовою як «між двома світами» [1]. Тому в даному випадку використання повного еквіваленту за допомогою буквального перекладу $\epsilon$ недоцільним.

Важливо пам'ятати, що в українських та англійських прислів'ях і приказках різні образи та символи використовуються для позначення однієї схожої (або тієї самої) речі або ідеї, явища; ці образи відображають різні соціальні стандарти та способи життя двох народів. Наприклад, прислів'я The grass is always greener on the other side of the fence дослівно перекладається як «трава завжди зеленіша по той бік паркану». Але в українській мові прямого еквіваленту до даної паремії не існує. Частковим відповідником такого прислів'я може бути приказка «добре там, де нас нема» [1, с. 615].

Також слід зауважити, що в кожній мові є фрази і стійкі вирази, які не можна сприймати буквально, навіть якщо розуміти семантичне та граматичне значення кожного слова. Ідея таких паремійне $\epsilon$ буквальною, а завуальованою. Спроби перекласти ці сталі вирази слово за словом можуть призвести до некоректного результату й грубих семантичних помилок. Так англійська приказка No room to swing a cat буквально перекладається як «немає місця, щоб розгойдувати кота» означає обмежений простір і має досить відмінну від тексту оригіналу українську інтерпретацію - «яблуку ніде впасти».

Вибираючи еквівалент англійських ідіом, фразеологічних одиниць, прислів”ів та приказок, перекладач повинен намагатися знайти граматичну або семантичну відповідність в обох виразах, наприклад:

- співвіднести деякі спільні частини мови (іменники, дієслова, дієприкметники): green with envy - позеленівши від заздрощів;

- шукати подібні синтаксичні структури: as a man sows, so shall he reap - що посієш - те й пожнеш. Або:

- As you make your bed, so must you lie in it - готуй сани влітку, а воза взимку [1]. 


\section{3. Типи відповідників для іншомовних пареміологічних одиниць}

Розглянемо основні три типи відповідників для іншомовних пареміологічних одиниць, які виокремлює Комісаров В.Н. Дослідник переконаний, що перший тип відповідників містить у собі весь комплекс значень мовної одиниці, що перекладається. У даному випадку в мові перекладу існує подібне прислів'я або приказка, що співпадає із текстом оригіналу як у своєму прямому, так і в переносному значенні й грунтується на образно-символічному тлі. Як правило, ці відповідники прослідковуються у так званих «інтернаціональних» пареміях, запозичених обома мовами 3 іншої мови, стародавньої або сучасної. Використання подібних еквівалентів найповніше передає ідею тексту оригіналу. Наприклад,

The game is not worth the candle $s$ - гра не варта свічок, або шкурка вичинки на варта.

To play in to some body's hands - грати комусь на руку.

Другий тип відповідників, згідно з даним дослідженням, передбачає відтворення однакового переносного значення у тексті перекладу за допомогою введення іншого, відмінного від першоджерела, образу та збереження решти семантичних компонентів паремії. Використання відповідників такого типу забезпечує досить високий рівень еквівалентності за умови, якщо українські паремії не відзначаються яскраво вираженим національним забарвленням.

To get up on the wrong side of the bed - встати не 3 тієї ноги.

A bird in the hand is worth two in the bush - краще синиця в руках, ніж журавель у небі [9].

Третій тип обумовлюється способом калькування тексту оригіналу: to put the cart befor ethe horse - ставити віз попереду коня. Відповідники цього типу можуть вживатися лише в тому випадку, якщо образ, що міститься у початковому варіанті тексту прислів'я або приказки, $\epsilon$ «прозорим», а його відтворення мовою перекладу дозволить реципієнту зрозуміти його значення та ідею в трансформованому варіанті. Якщо ж в оригіналі вжито фразеологічне зрощення, де зв'язок між прямим і переносним значенням недостатньо чіткий, то калькування образу призведе до руйнування сенсу всієї фразеологічної одиниці. У подібних випадках часто доводиться відмовлятися від застосування відповідника взагалі на користь опису основного (тобто переносного) смислу тексту оригіналу в тексті перекладу: 
Mind one's $P$ 's and $Q$ 's - бути обережним і ввічливим у певній ситуації яка цього вимагає.

To dine with Duke Humphrey - бути голодним, залишитися без обіду. Походження даної приказки сягає давнини, коли протягом певного часу боржники в Лондоні переховувались від кредиторів у Соборі Святого Павла, в якому знаходиться гробниця герцога Хамфрі. Так, на запитання про те, де вони будуть обідати, боржники відповідали, що з герцогом, тобто ніде. Таким чином, вони залишалися без їжі. Для того, щоб перекласти цю приказку та подібні фразеологічні одиниці, пов'язані 3 певними історичними подіями, необхідно ознайомитися 3 точними подіями того часу, на грунті яких вони й утворилися (цит. за: [7, с. 115]).

\section{4. Стратегії вибору перекладу ідіом}

Чимало вчених вивчали різні можливі способи перекладу прислів 'їв. За словами Бейкера, для перекладу ідіом або прислів'їв, перекладач може вибрати одну з чотирьох стратегій:

1) перша стратегія полягає у тому, щоб вибрати з мови перекладу стійке висловлювання, яке відповідає формі та значенню паремії мови оригіналу. У даному випадку, перекладач використовує ідіоматичне висловлювання мовиперекладу, яке складається зізначення ілексичного наповнення, що є подібними до мови оригіналу. Наприклад, прислів'я Beware of a silent dog and still water можна перекласти українською мовою такими способами: у тихому болоті чорти водяться, або тиха вода греблю (береги) рве.

2) Друга - має на меті знаходження в арсеналі ідіом і стійких висловлювань мови перекладу тієї мовної одиниці, що має однакове семантичне значення й ідейно-функціональну мету, але відмінну від мови оригіналу лексичну структуру.

3) Третій метод полягає у застосуванні парафрази. Він використовується у випадку, якщо у мові перекладу відсутній еквівалент тексту мови оригіналу, або якщо стилістика тексту перекладу відрізняється від необхідного зразка. Наприклад, англійська приказка Barkis is willing перекладається як Баркіс не проти.

4) Четверта стратегія характеризується використанням методу пропущення (Non-idiomatic translation). Згідно з даною стратегією, перекладач повністю видаляє частину тексту прислів'я, адже у мові 
перекладу немає еквівалентної або близької до значення мовної конструкції.

Даним методом перекладу також можна послуговуватися у разі, якщо перекладач працює зі специфічними мовними виразами, які вважаються табу в мові перекладу. Окремі дослідники наголошували на тому, що іноді доцільно не перекладати певні слова або фрази 3 мови оригіналу на мову перекладу.

Інколи для збереження автентичного смислу постає необхідність у використанні більше ніж однієї стратегії, оскільки «у багатьох випадках соціальне підгрунтя, яке лежить в основі мови оригіналу, вимагатиме адаптації, пояснення або перефразування, а не буквального перекладу» [5, с. 129].

Канадські лінгвісти Віне Ж.-П. і Дарбельне Ж. стверджують, що в окремих лінгвістичних одиницях, таких як прислів'я та приказки, «сенс» або «значення» $€$ пріоритетними категоріями для роботи перекладача. Це означає, що ці фразеологічні одиниці не обов'язково повинні відповідати стилістичним або структурним компонентам мови оригіналу. Метою $є$ передача необхідного семантичного та ідейного значення пареміологічної одиниці. Саме це явище науковці називають «рівноцінністю» під час перекладу стійких мовних одиниць [9, с. 38].

За словами Ніди, «прислів'я є особливими метафоричними виразами, й перекладач повинен знати необхідні поняття в обох мовах - оригіналу й перекладу. Це означає, що слід мати на увазі їх подібні риси та відмінності» [8, с. 14]. Таким чином, певні прислів'я і приказки можуть існувати як у мові оригіналу, так і в мові перекладу, але з різними значеннями. Це також може означати, що оригінальний варіант паремії може мати відповідник умові перекладу з аналогічною формально-граматичною структурою.

Зважаючи на те, що переклад - це процес взаємодії лінгвістики та культурної спадщини, у результаті якого породжується новий текст із заміною тексту оригіналу в іншу лінгвокультурну площину за допомогою еквівалентного тексту перекладу, мовознавці зазначають, що процес перекладу складається із трьох етапів:

1) надання семантичного та стилістичного значень мові оригіналу;

2) переклад вихідного тексту, результатом якого $є$ подальше створення перекладацької стратегії; 
3) відтворення вихідного тексту мовою перекладу шляхом використання мовних засобів та конструкцій, які повністю відповідають його семантичному значенню і комунікативній меті.

Крім загального сенсу, прислів'я і приказки несуть у собі образносмисловий зміст. Тому доцільним та ефективним, розглядаючи аспект їх національно-культурної специфіки, $\epsilon$ порівняльний лінгвокультурологічний аналіз англійських та українських прислів’їв.

\section{5. Категорії паремій}

Порівнюючи пареміологічну панораму англійської та української мов, слід розділити їх на кілька категорій, кожна 3 яких має свої особливості та специфіку перекладу:

1. Повні еквіваленти, коли англійські прислів'я та висловлювання повністю відповідають їхнім українським варіантам:

- As clear as day - ясно, як день.

- Health is better than wealth - здоров'я дорожче за гроші.

- A sound mind in a sound body - в здоровому тілі здоровий дух. Англійський та український варіанти даної фразеологічної одиниці грунтуються на анафорі, використанні спільної лексичної одиниці, що сприяє фокусуванню уваги на ключовому слові синтаксичної конструкції - «здоровий».

Англійське прислів'я He who chases two hares catches neither також має свій відповідник в українській мові: «За двома зайцями поженешся жодного не впіймаєш». У даному прикладі спостерігається повне збереження усіх значень фразеологічної конструкції. Однак, слід відзначити, що різниця у синтаксичних структурах англійської й української мов призводить до значних лексико-синтаксичних трансформацій за максимально повного збереження внутрішньої семантики [9].

Абсолютними еквівалентами англійських прислів '̈в і приказок $\epsilon$ наступні варіанти українських перекладів- відповідників:

- Better late, than never - краще пізно, ніж ніколи.

- Dog is man's best friend - пес - найкращий друг людини.

- Speech is silver but silence is gold - слово - срібло, мовчання золото.

- A skeleton in the closet - скелет у шафi.

- All that glitters is not gold - не все золото, що блищить. 
- The apple never falls far from the tree - яблуко від яблуні недалеко падає.

- Better die standing than live kneeling - краще вмерти стоячи, ніж жити на колінах.

2. Часткові еквіваленти, коли англійські прислів'я та приказки дещо відрізняються за своїм змістом від українських:

- To buy a pig in a poke - купити кота в мішку.

- Better an egg today than a hen tomorrow - краще синиця у руках, ніж журавель у небі.

- When it rains it rains on all alike - сонце на всіх однаково світить.

- A tree is known by its fruit - дерево славиться плодами, а людина - ділами.

- Many a little makes a mickle - щоб досягти великого, треба почати 3 малого.

- An Englishman's house is his castle - мій дім - моя фортеця.

- The eyes of fear see danger everywhere - у страху великі очі.

- The pen is mightier than the sword - що написано пером не вивезеш і волом.

- Too much knowledge makes the head bald - багато знатимеш швидко зістарієш.

- Don't make a mountain out of an ant hill - не роби з мухи слона [1].

У даному випадку варто підкреслити, що під час перекладу вищенаведених прислів 'їв, смисл, вкладений у текст перекладу, зберігається. Однак, для отримання більш точного перекладу, в нього були внесені деякі зміни. Так, наприклад, вихідний варіант прислів'я An Englishman's house is his castle пересічний українець не зміг би належним чином зрозуміти і застосувати в усному чи писемному мовленні, адже дане прислів'я відображає побут і характер саме англійців. У зв'язку з цим, воно було семантично та лексично трансформовано й адаптовано.

Використання фразеологізмів-аналогів дозволяє досягати досить високого ступеня еквівалентності, зберігати оригінальну семантику висловлювань, трансформуючи при цьому компонентний склад початкової англійської паремії. Головною відмінністю між текстом оригіналу і текстом перекладу в даному випадку є образ або символ, який покладений в основу паремії і несе метафоричний зміст. 
3. Відповідники-кальки $є$ результатом дослівного перекладу англійських фразеологічних конструкцій. До даної перекладацької стратегії вдаються у ситуації, коли прислів'я збігаються за значенням, але різняться своїм компонентним складом і образністю. Ми погоджуємося $з$ думкою Арнольд I.В., яка вважає, що зазначені «відмінності викликані унікальними особливостями менталітету, властивими тому чи тому народу й обумовлюють національну своєрідність порівнюваних мов» [2, с. 50].

У разі відсутності аналога в мові перекладу, метод калькування дозволяє зберегти внутрішній семантичний зміст прислів'я або приказки, передати образну побудову оригіналу Наприклад, Кеер а dog and bark oneself - собаку тримати, а гавкати самому.

Гаврин С.Г. переконаний, що відповідники-кальки володіють певними перевагами i досить широко використовуються у перекладацькій практиці. По-перше, тому що вони дозволяють залишати образну побудову оригіналу, а це є важливим у художньому перекладі. По-друге, вони дають можливість перекладачеві подолати труднощі, які виникають, коли в оригіналі образ трансформується для створення розгорнутої метафори [3, с. 36].

Цікавим є спостереження, що інколи перекладачам вдається впроваджувати в мову перекладу нові фразеологічні одиниці. Здебільшого це відбувається із фразеологізмами біблійного, античного або міфологічного походження і які є досить специфічними за своїм лексичним наповненням і глибоким метафоричним змістом. Під час перекладу текстів культурно-історичної тематики застосовують метод калькування поряд із поясненням в максимально стислому вигляді. Такий вид перекладу називається подвійним, або паралельним. При перекладі фразеологічної одиниці з однієї мови на іншу фахівці рекомендують користуватися найбільш повними й авторитетними українськими тлумачними фразеологічними словниками.

Головною особливістю відповідника-кальки $є$ те, що найчастіше вона не сприймається українським реципієнтом як фразеологічна конструкція через відсутність аналогів. Навпаки, вона відчувається іншомовною, чужою у порівнянні зі сталими пареміологічними одиницями рідної мови. Впізнавання, адекватна інтерпретація подібних виразів у рамках національної культури країни мови перекладу стає 
можливою лише за умови тривалого функціонування фразеологізму в мові перекладу [6]. Прикладами даного способу перекладу англійських прислів 'їв і приказок є наступні українські інтерпретації:

- Use your head to save your feet - сім разів відміряй - один відріж.

- To live in clover - купатися, як сир в маслі; жити, як вареник в сметані.

- Haste makes waste - поспішиш - людей насмішиш.

4. Англійські прислів'я та приказки, що не мають відповідних варіантів в українській мові потребують окремого спеціального пошуку та аналізу, які є основою описового перекладу:

- A cat falls on his legs - правда перемагає.

- There's many a slip between the cup and the lip - вилами по воді писано.

- Grin like a Cheshire cat - скалити зуби.

Дана перекладацька стратегія супроводжується втратою більшої частини лексико-семантичних значень фразеологічної єдності, однак дозволяє передати основне значення конструкції, сприяючи усуненню труднощів під час процесу перекладу протягом декодування іншомовного повідомлення [4]. Зазначений вид перекладу використовується, як правило, в ситуації передачі фразеологізмів, які моделюються на основі безеквівалентної лексико-семантичної структури, референти яких у рамках української культурної моделі відсутні.

Прикладами практичного використання вищезгаданої перекладацької стратегії можуть слугувати такі трансформації англійських прислів ’їв, українські відповідники яких знаходять своє відображення у наступних конструкціях:

- You can lead a horse to water, but you can't take it drink - неможливо змусити людину робити те, що їх не подобається. Дослівно дане англійське прислів'я звучить так: ти можеш підвести коня до води. Але ти не можеш змусити його пити.

- The lights are on but nobody's home. Дослівний переклад - світло ввімкнене, але нікого немає вдома. Однак, дане прислів'я несе зовсім інший зміст - «хтось дуже дурний», викриваючи недостатньо розумну людину.

- Rob Peter to pay Paul - позичати гроші в когось, аби віддати їх іншому. 
- There's one born every minute - таке стійке висловлювання також вживається, аби вказати на людину, яка не відзначається розумовими здібностями.

- It will be all right on the night - смисл даної паремії інтерпретується як підбадьорення і втішання - все (подія, захід) пройде добре, навіть якщо підготовка відбувалася безуспішно.

- Why keep a dog and bark yourself - навіщо робити щось самому, якщо хтось може зробити це за тебе?

- It's not over until the fat lady sings - дослівний переклад - ще не кінець, доки співає товста жінка. Семантичне значення даної приказки криється у наступному: поки щось не закінчилося, у людини завжди $€$ шанс [1].

\section{6. Відтворення у прислів'ях національних рис характеру}

Говорячи про національний характер англійців важко виокремити якусь його одну характерну рису. На території Великобританії, до складу якої входять декілька країн, мешкають англійці, шотландці, ірландці та інші. Характер народу не піддається однозначному опису. Він складається із безлічі ледь помітних рис, тонких відтінків. Національний характер не є постійним, він змінюється з часом, разом міною історичних умов, у яких живе нація.

Цікавість та допитливість у поєднанні 3 постійним бажанням розвиватися дозволилабританцямознайомитисяізцінноюетнокультурною спадщиною, якою нині послуговуються інші народи, залишаючись при цьому вірними рідним традиціям. Захоплюючись французькою кухнею, англієць не буде готувати іï вдома. При цьому недоцільно стверджувати, що англійські звичаї перебувають у постійній статиці й зовсім не змінюються. Трансформації і зрушення відбуваються, але вони не $\epsilon$ настільки видимими ззовні і не впливають на націю. Оригінальні автентичні особливості англійського менталітету та свідомості глибоко впливають на національний характер і загальний спосіб життя [2, с. 177].

Сучасні англійці сприймають поняття самоконтролю як головну перевагу людини як розумної істоти. Опис «вміють тримати себе в руках» якнайкраще виражає характерну внутрішню якість цієї нації, яка виявляється у природній стриманості та спокої. Чим краще людина здатна володіти власними емоціями та стійко переносити життєві 
«американські гірки», тим більше гідності вона має. 3 дитинства англійці звикають спокійно витримувати холод і голод, боротися зі страхами і болем, контролювати i, навіть, приборкувати прихильність i антипатію по відношенню до іншої людини. Їхній природі притаманна любов до порядку та комфорту. Вони полюбляють зручний транспорт, новий костюм, багату бібліотеку. Опинившись у епіцентрі певних людських турбот, справжнього англійця впізнати досить легко. Ніякий шум і плач не відволікають його від поставленої мети. Він не зупиняється ні на мить.

Якщо узагальнити відомості, що базуються на переконаннях видатних людей, або на загальноприйнятих істинах, можна простежити головні риси англійського національного характеру.

Англійці працелюбні та доводять будь-яку справу до кінця, у більшості випадків - до переможного. Витоками такого ставлення до справи вважають любов до порядку. Виховання дитини починається 3 появи іiї на світ.

Характерною рисою англійців є їхня акуратність по відношенню до грошей, їхня ощадливість. У них не прийнято дарувати дорогі подарунки. Подарунки повинні бути корисними та приємними, щоб не бути нікому зобов'язаним.

Англійці пунктуальні, коректні та ввічливі. Достатньо обережні, але й прямолінійні під час ведення ділових переговорів.

Отже, зупинимося та розглянемо більш детально риси характеру, що притаманні мешканцям країн Великобританії.

Спираючись на матеріал «Англо-українського фразеологічного словника» 3'ясуємо, що ж самі англійці говорять про різні види діяльності, до яких вони причетні.

1) Ставлення до справи, до роботи:

- Never put off till tomorrow what you can do today. - Ніколи не відкладай на завтра те, що можна зробити сьогодні.

- The cat would eat fish and would not wet her feet. - Щоб рибку з'їсти, треба в воду лізти.

- A cat in gloves catches no mice. - Любиш кататися - люби і саночки возити.

- He works best, who knows his trade (work goes with a swing under the master's hand). - Справа з людини майстра робить. 
- Work is not disgrace, the disgrace is idleness. - Праця людину годує, а лінь - марнує.

- Constant dropping wears the stone.-Під лежачий камінь вода не тече [1].

2) Англійська ощадливість:

- A penny saved is a penny gained. - Копійка гривню береже.

- The devil dances in an empty pocket. - В порожній кишені чорт танцює.

3) Пунктуальність:

- Time is money. - Час - це гроші.

- Punctuality is the politeness of kings. - Пунктуальність - ввічливість королів.

4) Обережність і точність:

- Haste makes waste. The less haste, the more speed. The more haste, the less speed. - Поспішиш - людей насмішиш.

- It is ill to waken sleeping dogs. Let sleeping dogs lie.- Не слід будити сплячих собак. Не буди лихо, поки воно спить.

- Measure thrice and cut once; look before you leap. - Сім разів відмір, один раз відріж.

- First think, then speak. - Спочатку подумай, потім говори.

- Never give the wolf to keep the weather. - Не пускай козла в город.

5) Стриманість і лаконічність:

- Bind the sack before it is full. - У всьому знай міру.

- Silence is golden. - Слово - срібло, мовчання - золото.

- A word spoken is past recalling. - Сказаного не повернеш.

- Sustain and abstain. - Стримайся і утримуйся.

- Better the foot slip than the tongue. - Слово не горобець: вилетить не впіймаєш.

- Words hurt more than swords. - Слова ранять сильніше, ніж мечі.

6) Освіченість та інтелектуальний розвиток:

- Wise catches the meaning at once; a word is enough to the wise. Мудрий із півслова розуміє.

- Money spent on the brain is never spent in vain. - Гроші, витрачені на освіту, завжди окуповуються.

- Live and learn. - Вік живи - вік учись.

- Zeal without knowledge is a runaway horse. - Завзяття без уміння не користь, а біда. 
- Two heads are better than one. - Одна голова добре, а дві - краще.

7) Суворе виховання і дисциплінованість:

- A good example is the best sermon. - Ніщо не переконує людей краще, ніж власний приклад.

- A man is known by the company he keeps. - Скажи,хто твій друг, і я скажу тобі, хто ти.

- Doing is better than saying. - Краще зробити, аніж сказати.

- He that lies down with dogs must rise up with fleas. - Із ким поведешся, від того й наберешся.

8) Любов до порядку, мудрості. Своєрідний педантизм.

- First come, first served. - Хто перший прийшов - той i знайшов.

- Be slow to promise and quick to perform. - Обіцяй мало, роби багато.

- Bind the sack before it be full. - Усьому знай міру.

- Catch the bear before you sell his skin. - Не поспішай ділити шкуру невбитого ведмедя, не кажи гоп, поки не перескочиш.

- Fool's haste is no speed. - Спішити - людей смішити [9].

Дослідивши цілу низку прислів 'їв та приказок бачимо, що поряд 3 загальними рисами характеру, які притаманні усім мешканцям Великобританії - працелюбність, пунктуальність, заощадливість, ввічливість, коректність - у кожній країні існують свої особливості, обумовлені географічним положенням, економічним розвитком чи історією регіону.

Здійснюючи переклад англійських паремій українською мовою, важливо брати до уваги семантико-образну, символічну наповненість стійкої мовної одиниці. Досліджуючи це питання, ми погоджуємося з думкою зарубіжних мовознавців, які переконані, що важливо перейти від інтуїтивного «спостереження за предметами мовлення» або концептів до детального аналізу смислового змісту і порівняння образів свідомостей, які знаходять конкретні відображення у лексичних одиницях, фразах і висловлюваннях в обох мовах. Наприклад, порівняння приказок Do not put all eggs into one basket «не порівнюй божий дар з яєчнею» або «не плутай грішне 3 праведним» демонструє, що одна й та ж думка висловлюється за допомогою різних культурно-смислових образів, символів i метафор. 
Ці дві приказки несуть у собі певну ідею, завданнями якої є:

- раціональна порада бути обережним та уважним у своїх судженнях, не робити завчасних висновків. Дане прислів'я також може сприйматися як попередження, пересторога;

- формулювання мудрого філософського висловлювання, яке $є$ приводом для роздумів.

Очевидно, що англійський менталітет, відображений у народних прислів'ях і приказках, найчастіше передбачає вирішення більш прагматичних ідейних завдань і побудову простіших смислових образів. Безумовно, дуже важливим $\epsilon$ аналіз національної та культурної специфіки прислів'їв і приказок різних країн, які подібні за загальним змістом, відображаючи близькі культурні звичаї та уявлення народів [2, с. 118].

Можливо, саме внаслідок загальної смислової близькості, прислів'я і приказки легко запам'ятовуються і в подальшому відтворюються. Разом $з$ тим, ми розділяємо думку Гапонів А.Б. і Возної М.О. про те, що смисловий зміст прислів'їв і приказок відбиває «національнокультурні особливості світобачення, образне уявлення дійсності, своєрідність життя, культури, історії народу» [4, с. 322]. На переконання багатьох фахівців, повноцінне психолінгвістичне вивчення прислів"їв і приказок можливо тільки в міждисциплінарному аспекті i, перш за все, в аспектах країнознавства, культурології, концепції міжкультурної комунікації, лінгвістичної семантики та лінгвофольклористики.

Отже, окреслимо труднощі під час перекладу англійських прислів 'їв і приказок:

1) специфічна концепція культури. Текст мови оригіналу може містити слово, яке є невідомим для культури країни мови перекладу;

2) концепція мови оригіналу не лексикалізована в мові перекладу. Певна лексема мови оригіналу може виражати поняття, яке відоме іншим мовам, але не є лексикалізованим, наприклад, «телебачення»;

3) лексична одиниця мови оригіналу є семантично складною. Вона може мати лише одну морфему, але при цьому бути семантично наповненою, наприклад, вигук «О!», який наповнений змістом відповідно до контексту;

4) складові мови оригіналу й мови перекладу мають різницю у значеннях. Значення стійкого вислову в першій може мати під собою 
глибинне значення у той час, як мова оригіналу може не вважати того актуальним взагалі;

5) у мові перекладу відсутній певний термін (hyponym), тому що кожна мова робить розмежування між цими словами саме в його конкретному середовищі. Наприклад, гіпонімами до слова «стаття» $\epsilon$ огляд, звіт, критика, коментар;

6) відмінності у фізичній або міжособистісної перспективі. Йдеться про те, яким чином речі, явища або люди ставляться один до одного, або до певних обставин і місць;

7) відмінності в експресивному значенні. У мові перекладу може міститися слово, яке має те ж саме пропозиційне значення, як і слово в мові оригіналу, але воно може мати інше виражально-зображальне значення. Так, перекладач додає певні художні засоби з метою увиразнення значення і еквівалентного прирівнення його до свого автентичного варіанту в мові оригіналу;

8) відмінності у формах. Перекладач повинен бути обережним, якщо немає еквіваленту для конкретного форму в мову оригіналу. Деякі суфікси та префікси, які передають певний тип значення не має еквівалентності іншою мовою;

9) використання запозичених слів у тексті оригіналу, що створює певні проблеми створює деякі проблеми при перекладі.

Вищеназвані особливості прислів”ї і приказок, які стосуються ïx походження семантичного значення, граматико-синтаксичної структури ускладнюють процес перекладу й потребують детального аналізу та ретельної праці перекладача над текстами обох мов. Саме від урахування цих специфічних рис залежить вибір методів та прийомів перекладу, а також його якісна реалізація.

Абиподолати вищеназвані труднощі й правильно здійснитипереклад і якомога точніше інтерпретувати прислів'я та приказку, слід спочатку визначити, чи використовується така стійка одиниця в українській мові і чи відповідає вона значенню паремії, що перекладається. Якщо ж прямих аналогів немає, необхідно знайти й підібрати такі еквіваленти, які будуть відрізнятися тільки морфологічним складом. При відсутності таких, слід шукати слова, які за забарвленням i значенням збігаються із компонентним складом тексту оригіналу. Тільки після того, як перекладач переконається, що жоден із цих 
методів перекладу не є дієвим для конкретної пареміологічної одиниці, він може послуговуватися такими варіантами перекладу, які будуть відповідати оригіналу за значенням, але повністю відрізнятиметься своєю структурно-граматичною оформленістю

\section{7. Висновки}

У даному дослідженні характеризовано структурносемантичні ознаки прислів'їв і приказок англійської мови, а також досліджено семантику фразеологізмів англійської мови 3 точки зору відображення у них національної своєрідності народуносія. 3'ясовано, що переклад прислів'їв і приказок, підбір його оптимального методу залежить від етимологічних, лексикосемантичних i структурних особливостей тексту оригіналу. Окрім того, простежено зв'язок між пареміями та історикокультурними умовами розвитку англійського народу, що свідчить про відображення у них національної свідомості та звичаїв етносу, які формувалися протягом багатьох сотень років. Нами доведено, що англійським пареміям притаманні лаконічність, глибока змістова наповненість, структурно-композиційна завершеність, наповненість багатьма художніми засобами, ритмомелодійність, символічність і метафоричність. Розглянуто диференціацію підходів до перекладу англійських паремій і здійснено порівняльний аналіз англійських й українських прислів'їв та приказок, враховуючи перекладацький аспект. Окреслено основні труднощі інтерпретації паремій із тексту оригіналу в текст перекладу, до яких віднесено: відсутність подвійного заперечення в англійській мові, дотримання сталого порядку слів у мові оригіналу, омонімія і використання багатозначних слів, а також етнокультурні особливості, риси яких не демонструються у мові перекладу.

Комплексний характер роботи розширює поле для досліджень проблеми вживання та перекладу англійських прислів'їв і приказок, а також може стати у пригоді при створенні підгрунтя подальшій науково-дослідній розробці даної проблематики. Обробка отриманих даних допоможе перекладачеві в майбутньому швидше та ефективніше здійснювати інтерпретацію текстів мовою оригіналу. 


\section{References:}

1. English-Ukrainian phraseological dictionary / Compiled by K.T. Barantsev. 2nd ed., corrected. K.: "Znannya", KOO, 2005. 1056 p.

2. Arnold I.V. (2009). Stylistics of modern English language (decoding stylistics). M.: Flinta: Nauka, 384 p.

3. Gavrin S.G. (1974). Phraseology of modern Russian. Perm, 256 p.

4. Gaponov A.B., Vozna M.O. (2005). Linguistics. English speaking countries. Textbook for university students and teachers. Vinnytsia : Nova Knyga, 464 p.

5. Gedzur S.V. (2010). English idioms, phraseologisms, proverbs. H.: Publishing Group "Osnova", 144 p.

6. Korunets I.V. (2003). Comparative typology of English and Ukrainian. Vinnytsia: Nova Knyga, 464 p.

7. Ter-Minasova S.G. (2000). Language and intercultural communication: Textbook. M., $262 \mathrm{p}$.

8. Nida E. (1985). Translating means Translating meaning: A Sociosemiotic Approach to Translation. Leiden: E.J. Brill.

9. Tomas A. Green. (1997). Folklore : an Encyclopedia of Beliefs, Customs, Tales, Music, and Art. Oxford : ABC-CLIO, 892 p. 